Kumawula, Vol. 4, No.1, April 2021, Hal 43 - 48

DOI: https://doi.org/10.24198/kumawula.v4i1.30570

ISSN 2620-844X (online)

Tersedia online di http://jurnal.unpad.ac.id/kumawula/index

\title{
PEMBERDAYAAN MASYARAKAT MELALUI PELATIHAN PENDAMPINGAN PENYUSUNAN BUKU PROFIL DESA SINGOYUDAN, MIRIT, KEBUMEN BERBASIS SISTEM INFORMASI DAN KOMUNIKASI ONLINE (SISKON)
}

\author{
Sakir $^{1 *}$, Laras Astuti ${ }^{2}$, Aswad Ishak ${ }^{3}$ Bhakti Gusti Walinegoro ${ }^{4}$, Alfi Novriando ${ }^{5}$ \\ ${ }^{1}$ Universitas Muhammadiyah Yogyakarta \\ ${ }^{2}$ Universitas Muhammadiyah Yogyakarta \\ ${ }^{3}$ Universitas Muhammadiyah Yogyakarta \\ ${ }^{4}$ Universitas Muhammadiyah Yogyakarta \\ ${ }^{5}$ Universitas Muhammadiyah Yogyakarta \\ *mas.sakir@fisipol.umy.ac.id
}

\begin{abstract}
Community service activities were implemented with two programs, making village profile books and strengthening village information systems in Singoyudan, Mirit, Kebumen Districts. The potential that is owned by the village must be able to become the identity of the development of village progress. The method used is to provide assistance and involve students of the Muhammadiyah University of Yogyakarta to directly go into the area and develop / making village profile books and create a website as well as training to create reliable human resources. The outputs resulting from this community service include: First, Singoyudan Village already has a village profile book with the latest edition and with additional information needed. Second, Singoyudan Village has an active website and social media that contains information on villages. Developments that need to be done after this program include updating the latest village profile and the use of social media in offering services other than the website that has been created.
\end{abstract}

Keywords : Village Profile Book, Village Assistance, Strengthening Village Information Systems, SISKON

\begin{abstract}
ABSTRAK
Kegiatan pengabdian masyarakat dilaksanakan dengan dua kegiatan utama yaitu Pembuatan Buku Profil Desa dan Penguatan Sistem Informasi Desa (SID) di Desa Singoyudan, Kecamatan Mirit, Kabupaten Kebumen. Potensi yang dimiliki oleh desa harus dapat menjadi jati diri pengembangan kemajuan desa. Metode yang digunakan adalah dengan melakukan pendampingan dan melibatkan mahasiswa Universitas Muhammadiyah Yogyakarta untuk secara langsung terjun ke lapangan dan mengembangkan/menyusun profil dusun dan pembuatan website serta pelatihan untuk mewujudkan SDM yang handal. Output yang dihasilkan dari pengabdian masyarakat ini antara lain: Pertama, Desa Singoyudan telah memiliki buku profil desa dengan edisi terbaru dan dengan penambahan informasi-informasi yang diperlukan. Kedua, Desa Singoyudan memiliki website dan media sosial aktif yang berisi informasi-informasi desa dan dusun. Pengembangan yang perlu dilakukan setelah program ini antara lain pembaharuan profil dusun yang up-to-date serta pemanfaatan media sosial dalam pemberian pelayanan selain website yang telah dibuat.
\end{abstract}

Kata Kunci: Buku Profil Desa, Pendampingan Desa, Penguatan Sistem Informasi Desa, SISKON.

\section{PENDAHULUAN}

Berlakunya Undang-Undang Nomor 6

Tahun 2014 tentang Desa memberikan paradigma baru tentang kebijakan tata kelola desa. Undang-undang tersebut menempatkan desa sebagai wilayah terdepan pembangunan Indonesia yang memiliki kewenangan untuk 
mengurus atau mengelola pemerintahan, pembangunan maupun pengelolaan keuangan desa secara mandiri (Turmudi, 2017). Adanya kebijakan desentralisasi fiskal dari pemerintah pusat berupa Dana Desa (DD) serta adanya Alokasi Dana Desa (ADD) dari pemerintah daerah menjadi bukti bahwa desa terus didorong untuk melakukan percepatan pembangunan dan peningkatan kesejahteraan penduduk desa. Selain itu, desa pun memiliki beragam potensi yang dapat mendukung pembangunan perekonomian (Herdiansah, 2020). Kunci penting dalam pengelolaan dana yang diperoleh desa adalah adanya data yang terkait tentang desa meliputi data kependudukan, kelembagaan, dan karakteristik desa (Asrori dan Agus, 2014: 283). Semua data yang dibutuhkan pemerintah desa tersebut dapat diintegrasikan ke dalam satu wadah yang disebut profil desa.

Mengingat pentingnya ketersediaan informasi tentang desa/kelurahan, pemerintah lalu mengatur perihal penyusunan profil desa dalam Peraturan Menteri Dalam Negeri Nomor 12 Tahun 2007 tentang Pedoman Penyusunan dan Pendayagunaan Data Profil Desa dan Kelurahan (Achsin, Cangara, \& Unde, 2015). Profil desa memuat berbagai data informasi meliputi data dasar kependudukan, potensi sumber daya alam dan sumber daya manusia, kelembagaan, sarana dan prasarana, serta perkembangan kemajuan dan permasalahan yang dihadapai desa. Adapun manfaat dari profil desa antara lain menjadi pedoman dalam menentukan kebijakan atau program-program pemberdayaan, membantu dalam penyusunan rencana pembangunan desa, serta mempermudah penggambaran potensi dan tingkat perkembangan desa yang akurat dan komprehensif. Wadah umum dari profil desa biasanya berbentuk buku profil desa. Akan tetapi, karena data tentang desa selalu mengalami perkembangan dan harus selalu diperbarui, maka perlu adanya suatu sistem yang dapat berfungsi untuk mengembangkan atau memperbarui profil desa setiap saat dengan prinsip efektif dan efisien. Sistem tersebut biasa disebut dengan sistem informasi dan komunikasi online (Siskon) yang berwujud website dan/atau media sosial. Adapun manfaat dari penyusunan buku profil desa yang berbasis Siskon antara lain penyusunan, pengembangan, pembaruan buku profil desa akan lebih efisien dan efektif, terwujudnya pemerintah desa yang transparan dan akuntabel, peningkatan layanan publik, kemudahan dalam mengakses informasi desa, dan peningkatkan partisipasi warga dalam pembangunan desa dan peningkatan kesejahteraan masyarakat. (Peraturan Menteri Dalam Negeri Nomor 12 Tahun 2007 tentang Pedoman Penyusunan dan Pendayagunaan Data Profil Desa dan Kelurahan, 2007)

Desa Singoyudan merupakan salah satu desa yang terletak di Kecamatan Mirit Kabupaten Kebumen Provinsi Jawa Tengah. Luas wilayah Desa Singoyudan adalah $1,78 \mathrm{~km}^{2}$ atau 3,4\% dari luas wilayah Kecamatan Mirit $\left(52,35 \mathrm{~km}^{2}\right)$. Luas wilayah tersebut terdiri dari lahan sawah seluas 119,87 ha tanpa irigasi dan lahan kering seluas 57,91 ha. Desa Singoyudan terdiri dari dua dusun, dua RW dan tujuh RT. Pada tahun 2018, jumlah penduduk Desa Singoyudan adalah 1.150 jiwa, terdiri 572 lakilaki dan 578 perempuan. Adapun potensi 
ekonomi yang dimiliki Desa Singoyudan antara lain pertanian (padi, jagung, kacang tanah, cabai merah, cabai rawit), peternakan (sapi potong, kuda, kambing, domba, ayam kampung, itik, dan itik manila), perikanan laut, industri mikro dan kecil (gula kelapa, emping melinjo, tahu dan tempe, kue basah, penggilingan padi, dan pengelohan kayu). Hal ini menunjukkan bahwa potensi ekonomi Desa Singoyudan sangat beragam dan memiliki peluang besar untuk dikembangkan (Kebumen, 2019).

Akan tetapi, Desa Singoyudan belum memiliki buku profil desa yang dijadikan sebagai pedoman untuk menentukan kebijakan pembangunan dan peningkatan kesejahteraan masyarakat. Tidak adanya buku profil desa menyebabkan pemerintah desa tidak dapat mengetahui secara detail tentang gambaran potensi dan tingkat perkembangan desa yang akurat, komprehensif dan integral. Selain itu, warga Desa Singoyudan sendiri juga tidak mengetahui dengan jelas informasi tentang desanya, baik data kependudukan maupun potensi-potensi apa saja yang dimiliki oleh desanya. Tidak adanya profil desa di Desa Singoyudan berdampak pada pembangunan dan tingkat kesejahteraan masyarakat di Desa Singoyudan. Hal tersebut dapat dilihat dari masih banyaknya keluarga yang berstatus pra sejahtera di Desa Singoyudan, yaitu 117 keluarga dari 352 keluarga (Muhammad, 2020).

\section{METODE}

Kegiatan Program Kemitraan Masyarakat (PKM) Pendampingan Penyusunan Buku Profil Desa Singoyudan, Mirit, Kebumen Berbasis Sistem Informasi dan Komunikasi Online (Siskon) dilaksanakan berdasarkan hasil observasi kondisi nyata di Desa Singoyudan oleh tim pengusul. Desa Singoyudan belum memiliki Buku Profil Desa yang lengkap memuat informasi kondisi desa dan data kependudukan. Selain itu, Pemerintah Desa Singoyudan belum mengoptimalkan Sistem Informasi Desa (SID) melalui website dan media sosial. Padahal, adanya media sosial dapat mempermudah penggunanya dalam berpartisipasi, berbagi, dan berkomunikasi (Susanti, Gunawan, \& Sukaesih, 2019). Maka dari itu, media sosial dapat digunakan untuk meningkatkan transparansi pemerintah desa dan dapat memudahkan akses informasi sekaligus mempublikasikan potensi yang dimiliki Desa Singoyudan.

Sesuai permasalahan yang terjadi di Desa Singoyudan, Pendampingan Penyusunan Buku Profil Desa Berbasis Sistem Informasi dan Komunikasi Online (Siskon) dilaksanakan melalui beberapa tahapan, sebagai berikut:

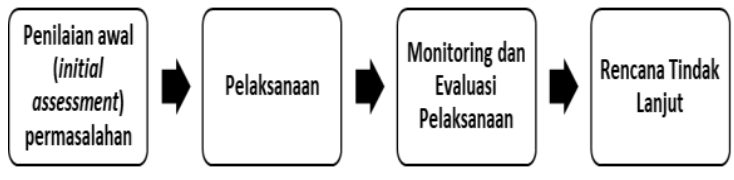

Gambar 1 Tahapan Pendampingan Penyusunan Buku Profil Desa Berbasis Sistem Informasi (Muhammad, 2020)

\section{HASIL DAN PEMBAHASAN}

Hasil yang dicapai dalam pelaksanaan Program Kemitraan Masyarakat ini, antara lain :

1. Buku Profil Desa Singoyudan

Buku Profil Desa Singoyudan yang memuat data lengkap desa meliputi data dasar kependudukan, potensi sumber daya alam dan sumber daya manusia, kelembagaan, sarana 
dan prasarana, serta perkembangan kemajuan dan permasalahan yang dihadapai desa. Buku profil desa ini dapat menjadi pedoman pemerintah desa dalam menentukan kebijakan atau program-program pemberdayaan, membantu dalam penyusunan rencana pembangunan desa, mempermudah penggambaran potensi dan tingkat perkembangan desa yang akurat dan komprehensif. Sifat dari buku profil desa bukanlah permanen, melainkan dapat berubah apabila ada perubahan terkait data yang termuat di dalamnya, misalnya data kependudukan atau ditemukannya potensi alam yang baru.

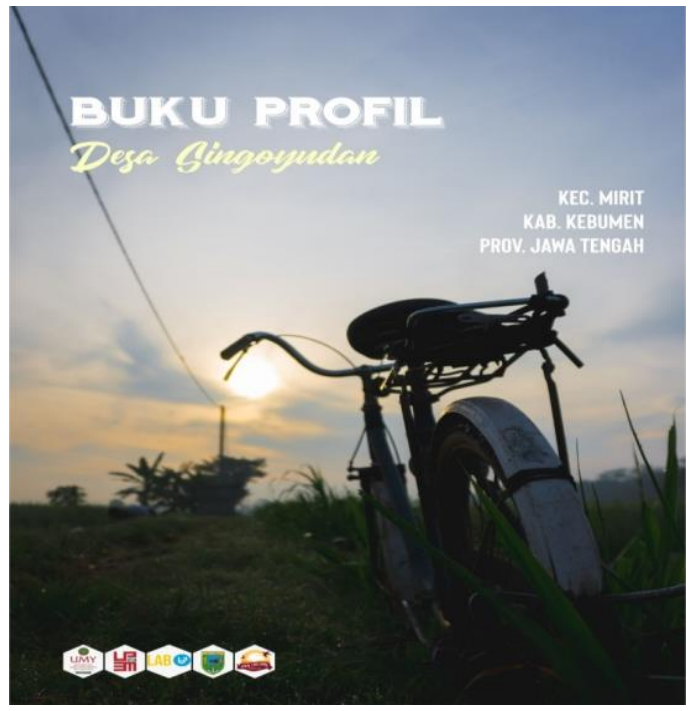

Gambar 2. Sampul Buku Profil Desa

Singoyudan (Muhammad, 2020)

Data dalam Buku Profil Singoyudan merupakan data baru dan validitasnya dapat dipertanggungjawabkan. Data tersebut didapatkan dari Laporan Tahunan Desa Singoyudan 2018 dan 2019 yang memuat informasi tentang desa dan didapatkan melalui sensus kependudukan Desa Singoyudan dengan lingkup sensus kependudukan mencakup satu desa yang terdiri dari tujuh RT dengan keterangan empat RT di Dusun Kademangan dan tiga RT di Dusun Gasaran. Adapun narasumber dalam sensus penduduk tersebut diantaranya adalah Situr selaku Kepala Desa Singoyudan, Perangkat Desa Singoyudan, BPD (Badan Permusyawaratan Desa) Singoyudan, KPMD (Kader Pemberdayaan Masyarakat Desa) Singoyudan, LKMD (Lembaga Ketahanan Masyarakat Desa) Singoyudan, Lembaga Perlindungan Masyarakat (Lipmas) Singoyudan, PKK Singoyudan, Karang Taruna Singoyudan, Tokoh Masyarakat dan masayarakat Desa Singoyudan. Sensus tersebut dilaksanakan pada tanggal tanggal 20-23 Januari 2020 pada pukul 08.00 sd 17.00 WIB setiap harinya (Muhammad, 2020).

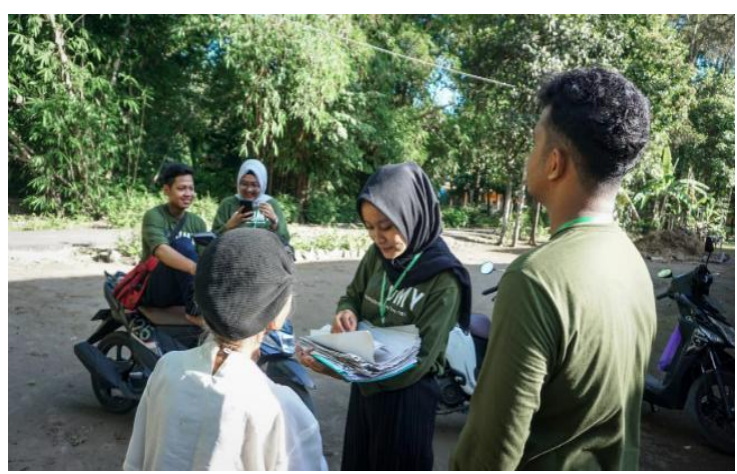

Gambar 3. Pengumpulan Data

Kependudukan (Muhammad, 2020)

2. Penguatan Sistem Informasi Desa

Proses pengumpulan data dan pembuatan profil desa menjadi buku dilaksanakan mulai tanggal 15 Januari - 3 Februari 2020 pada pukul 10.00 16.00 WIB. Data yang telah terkumpul 
juga dijadikan sebagai bahan pembuatan Video Profil Desa Singoyudan. Video tersebut nantinya akan dipublikasikan di media sosial Desa Singoyudan yang akan dibuat.

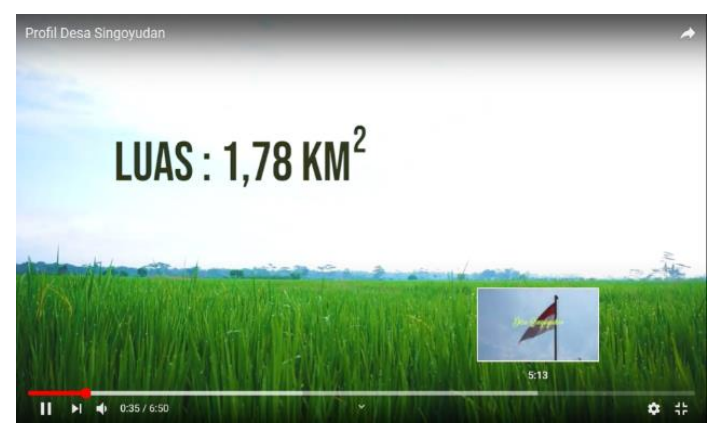

Gambar 4. Tampilan Video Profil Desa

Singoyudan (Muhammad, 2020)

Faktor pendukung dalam program ini ialah terlibat aktifnya peran perangkat desa, organisasi pemerintahan desa, tokoh masyarakat, dan warga Desa Singoyudan dalam memberikan informasi mengenai Desa Singoyudan. Sedangkan, faktor penghambatnya ialah kurangnya validitas data kependudukan yang diberikan oleh pemerintah desa, sehingga diperlukan rencana tindak lanjut yaitu sensus kependudukan Desa Singoyudan yang memuat jumlah penduduk, jumlah KK, jumlah penduduk berdasarkan umur, jumlah penduduk berdasarkan agama, jumlah penduduk berdasarkan pendidikan, jumlah penduduk berdasarkan pekerjaan, potensi perternakan, potensi industri mikro, dan sarana perdagangan yang terdapat di Desa Singoyudan.

\section{SIMPULAN}

Keberhasilan dalam pelaksanaan pengabdian masyarakat yaitu terbentuknya Buku Profil Desa Singoyudan dengan data terbaru dan lengkap, serta memiliki desain yang menarik. Buku profil ini akan memudahkan warga atau pengunjung yang ingin mencari tahu informasi tentang desa. Selain itu, pengabdian masyarakat ini juga berhasil membuat dan mempublikasikan Video Profil Desa Singoyudan yang dapat menjadi media informasi dan promosi tentang Desa Singoyudan kepada publik.

\section{UCAPAN TERIMA KASIH}

Penulis mengucapkan terimakasih kepada Lembaga Penelitian, Publikasi dan Pengabdian Masyarakat Universitas Muhammadiyah Yogyakarta atas dukungannya selama penulis melakukan pengabdian di Singoyudan, Mirit, Kebumen. Selain itu penulis juga mengucapkan terimakasih kepada seluruh perangkat Desa Mirit, tim KKN 149, dan pihak terkait atas bantuannya selama penulis melakukan pengabdian.

\section{DAFTAR PUSTAKA}

Achsin, S. N., Cangara, H., \& Unde, A. A. (2015). PROFIL DESA DAN KELURAHAN SEBAGAI SUMBER INFORMASI: STUDI EVALUASI TENTANG PENYEDIAAN INFORMASI POTENSI DESA DAN KELURAHAN DI SULAWESI SELATAN OLEH BADAN PEMBERDAYAAN MASYARAKAT PEMERINTAHAN DESA DAN KELURAHAN (BPMPDK) PROVINSI SULAWESI SELATAN. KAREBA: Jurnal Komunikasi, 4(4), 449-467.

Herdiansah, A. G. (2020). PENGEMBANGAN POTENSI KEWIRAUSAHAAN DENGAN PRINSIP PENTA HELIX DI DESA MARGAMEKAR KABUPATEN SUMEDANG. Kumawula: Jurnal Pengabdian Kepada Masyarakat, 3(3), 539-547. https://doi.org/https://doi.org/10.24198/k umawula.v3i3.31078

Kebumen, B. P. S. K. (2019). Kecamatan Mirit Dalam Angka 2019. 
Muhammad, I. (2020). Laporan Akhir KKN Kelompok $149 \quad$ Universitas Muhammadiyah Yogyakarta.

Peraturan Menteri Dalam Negeri Nomor 12 Tahun 2007 tentang Pedoman Penyusunan dan Pendayagunaan Data Profil Desa dan Kelurahan. , (2007).

Susanti, S., Gunawan, W., \& Sukaesih, S. (2019). Pengembangan Pemasaran Bordir dan Kelom Geulis Tasikmalaya Melalui Media Sosial. Jurnal Kumawula: Jurnal Pengabdian Kepada Masyarakat, 2(3), 248-261. https://doi.org/http://10.24198/kumawul a.vli3.25256

Turmudi, H. (2017). Desa dan Otonomi Asli (Studi Tentang Perangkat Desa Menuju Terciptanya Desa yang Berotonomi Asli). Universitas Muhammadiyah Surakarta. 